\title{
Erratum to: Ability of Two Dam Fine-Grained Sediments to be Used in Cement Industry as Raw Material for Clinker Production and as Pozzolanic Additional Constituent of Portland-Composite Cement
}

\author{
Antoine Faure ${ }^{1,2} \cdot$ Agnès Smith $^{2} \cdot$ Coryse Coudray $^{1} \cdot$ Baptiste Anger $^{1}$. \\ Horacio Colina ${ }^{3} \cdot$ Isabelle Moulin $^{4} \cdot$ François Thery ${ }^{1}$
}

Published online: 3 July 2017

(c) The Author(s) 2017. This article is an open access publication

\section{Erratum to: Waste Biomass Valor \\ DOI 10.1007/s12649-017-9870-8}

The article [Ability of Two Dam Fine-Grained Sediments to be Used in Cement Industry as Raw Material for Clinker Production and as Pozzolanic Additional Constituent of Portland-Composite Cement], written by [Antoine Faure], was originally published electronically on the publisher's internet portal (currently SpringerLink) on March 9, 2017 without open access.
With the author(s)' decision to opt for Open Choice the copyright of the article changed on July 1, 2017 to $\odot$ The Author(s) [2017] and the article is forthwith distributed under the terms of the Creative Commons Attribution 4.0 International License (http://creativecommons.org/licenses/ by/4.0/), which permits use, duplication, adaptation, distribution and reproduction in any medium or format, as long as you give appropriate credit to the original author(s) and the source, provide a link to the Creative Commons license and indicate if changes were made. The original article was corrected.

The online version of the original article can be found under doi:10.1007/s12649-017-9870-8.

Antoine Faure

antoine.faure@etu.unilim.fr

1 EDF R\&D, Eco-efficiency and Industrial Process

Department, Les Renardières, 77818 Moret-sur-loing, France

2 Univ. Limoges, CNRS, ENSCI, SPCTS, UMR 7315,

87000 Limoges, France

3 ATILH, 92974 Paris-la-Défense, France

4 LERM, 13631 Arles, France 